УДК 633.11.502:175

(C) 2017

Гавриленко О. С., кандидат ветеринарних наук, Хоміцька О. А., завідувач сектору мікробіологічних випробувань,

Загорулько О. В., старший науковий співробітник

Український державний науково-дослідний інститут «Ресурс»

\title{
ЕКСПЕРТНІ ДОСЛІДЖЕННЯ М'ЯСА ТА М'ЯСНИХ ПРОДУКТІВ
}

\section{Рецензент - кандидат ветеринарних наук В. М. Муковоз}

У статті наведено результати досліджень якосmі та безпечності м'яса та ковбасних виробів українських виробників за органолептичними, фізикохімічними та мікробіологічними показниками. Проаналізовано основні показники безпечності продуктів, які реалізуються в торговій мережі. По результатам досліджень встановлено основні причини невідповідності згідно з діючими стандартами - ие показник загального мікробіологічного забруднення (МАФАМ) і перевищення кількості бактерій групи кишкових паличок, щуо свідчить про порушення технологічних режимів та санітарно-гігієнічних вимог виробництва, зберігання, транспортування та реалізайіï.

Ключові слова: м'ясо, ковбасні вироби, якість, безпечність, мікроорганізми, невідповідність.

Постановка проблеми. У сучасних умовах ринкових відносин і зростання споживчого попиту на м'ясні продукти виникає потреба щодо підвищення вимог до їх якості та безпечності. В останні роки ця проблема стає ще більш актуальною. За даними ВО3 у світі щорічно гине близько двох мільйонів людей саме через біологічне та хімічне забруднення продуктів [16].

Аналіз основних досліджень і публікацій, у яких започатковано розв'язання проблеми. Споживачеві пропонують широкий спектр продуктів харчування з красивою рекламою, але під час досліджень часто виникають сумніви щодо їх якості. Особливо це стосується продуктів тваринного походження - м'яса та м'ясних продуктів, оскільки вони можуть бути причиною виникнення харчових отруєнь та токсикоінфекцій $[12,13]$. Контроль якості м'ясних продуктів - це питання завжди буде актуальним. 3 розвитком ринкової економіки в м'ясній промисловості стало більше можливостей фальсифікацій - не регламентовано використовуються «замінники м'яса», неякісна низькосортна сировина, субпродукти і т.д. [13]. Ці продукти підлягають ретельному санітарному контролю на кожному етапі технологічного процесу (забою, виробництві, транспортуванні, зберіганні та реалізаціі). Забезпечити контроль якості цих продуктів можливо завдяки комплексному підходу до цієї проблеми, тобто, потрібно проводить комплексне дослідження, яке має бути направлене на виявлення мікробіологічних, органолептичних та фізикохімічних показників у продукті. Всі показники визначаються нормативними документами, орієнтованими на міжнародні та європейські стандарти на дані продукти. Це є складовою частиною системи технічного регулювання та забезпечення якості продукції, що реалізовується на ринках України [13, 16-18].

Мета досліджень - встановити відповідність м'яса та м'ясних продуктів нормативним документам за органолептичними, фізико-хімічними та мікробіологічними показниками.

Завдання дослідження:

1. Провести дослідження на якість і безпечність м'яса та ковбасних виробів згідно 3 нормативною документацією національних стандартів [1-11].

2. Визначити основні причини невідповідностей критеріїв безпеки для використаних продуктів згідно з діючими стандартами.

Матеріали і методи досліджень. Об'єктами досліджень були 6 зразків м'яса та 3 зразки ковбасних виробів українських виробників: ТОВ «Візит», ПП «Ян Тас», ТОВ «Свро-Комерс», ТОВ «Профіт-люкс» та ТОВ «Еремієвський м'ясокомбінат». Дослідження проводили за договором №162054 від 22.06.2016 р. Зразки були відібрані згідно з актом випадкового відбору харчових продуктів і доставлені в лабораторію УкрНДІ «РЕСУРС», де і проводились експертні дослідження. Лабораторія акредитована Національним агентством 3 акредитації України на технічну компетентність та незалежність згідно зі стандартом ДСТУ ISO/IEC 17025:2006, що дає ій право проводити випробування харчових продуктів та продовольчої сировини на відповідність вимогам чинної нормативної документації.

Комплексне дослідження м'яса проводили на відповідність ГСТУ 46.019-2002, МБТ 5061-89, Обов'язковому мінімальному переліку від 03.11.98 № 16 зі змінами від 18 листопада 2003 р. 


\section{СІЛЬСЬКЕ ГОСПОДАРСТВО. ТВАРИННИЦТВО}

№ 87 та ДСТУ 6030:2008 [6, 8, 14, 15]. Органолептичні показники (зовнішній вигляд і колір туші, м'язи на розрізі, консистенція, запах та стан жиру, прозорість та аромат бульйону) досліджували згідно з ГОСТ 7269-79 [4], фізикохімічний показник на свіжість згідно з ГОСТ 23392-78 [3], мікробіологічні дослідження на загальну кількість бактерій (МАФАМ), бактерії групи кишкових паличок (БГКП) та патогенні мікроорганізми досліджували згідно 3 ГОСТ 10444.15-94, ГОСТ 21237-75 та ДСТУ ЕN 12824:2004 [1, 2, 9]. Мікроскопію мазківвідбитків м'яса проводили згідно з ГОСТ 2339278 [3].

Комплексне дослідження ковбасних виробів проводили на відповідність ДСТУ 4436:2005 [7].

Результати досліджень. У даній роботі було досліджено три зразки м'яса ТОВ «Візит» та по одному зразку виробників: ПП «Ян Тас», ТОВ «Євро-Комерс» і ТОВ «Профіт-люкс».

По результатам проведених випробувань м'яса мороженого (два зразки свинини та один яловичини) виробників ТОВ «Візит» (один зразок), ПП «Ян Тас» та ТОВ «Свро-Комерс» м'ясо відповідало показникам якості згідно 3 НД. За органолептичними дослідженнями зразки відповідали показникам свіжого м'яса: поверхня була вкрита шкірочкою підсихання, жир м'який, частково забарвлений в яскраво-червоний колір, м'язи на розрізі злегка вологі, на фільтрувальному папері залишали незначну пляму, або зовсім не залишали слідів; колір характерний для м'яса певного виду: яловичина - від світло до темночервоного, свинина - світло-рожевого. По консистенції - на розгині м'ясо щільне, пружне, в разі натискання ямка вирівнювалася відразу. Запах властивий кожному виду свіжого м'яса. Жир свинини був м'який, еластичний, блідо-рожевого кольору, яловичини - жовтий $з$ твердою консистенцією, під час натискування - крихким, без запаху осалювання та згіркнення. Бульйон прозорий, ароматний $з$ жиром на поверхні у вигляді великих крапель. По фізико-хімічному показнику свіжості зразки відповідали теж ознакам свіжого м'яса. За мікробіологічним показником загальної кількості бактерій (МАФАМ) м'ясо відповідало нормативам, бактерії групи кишкових паличок та патогенні мікроорганізми, у т. ч. бактерії роду Salmonella не виявлено. Під час мікроскопії мазків-відбитків м'ясо теж мало всі ознаки свіжого - в мазках не виявлено мікрофлори або поодинокі коки в полі зору, не було слідів розпаду м'язової тканини.

Один зразок м'яса яловичини ТОВ «Профітлюкс» по всім дослідженням відповідав показ- никам сумнівної свіжості. По зовнішньому вигляду і кольору туші поверхня зразків місцями була зволожена, злегка липка, потемніла або суха, сірувато-коричневого кольору. М'язи на розрізі вологі, залишали пляму на фільтрувальному папері площею, рівною площі дотику, липкі, темно-червоного кольору. Консистенція м'яса не достатньо щільна та пружна, запах кислуватий. Стан жиру - матовий з сіруватим відтінком, злегка липне до пальців та зі слабким запахом осалювання. Бульйон із запахом не властивим свіжому бульйону $з$ дрібними краплинами жиру на поверхні. Під час мікроскопії в мазках-відбитках виявляли грам-позитивні коки 11-15 клітин та грам-негативні палички 10-14 в полі зору, частини волокон м'язової тканини зі слабо помітною смугастістю. Загальна кількість бактерій в цих зразках не відповідала нормативам - цей показник був завищений, що свідчить про високий рівень забруднення продукції різними видами мікроорганізмів - як наслідок недотримання належних санітарних умов під час виробництва, зберігання і транспортування.

За мікробіологічними показниками не відповідали НД два зразки м'яса ТОВ «Візит» - підвищена кількість бактерій групи кишкових паличок і під час мікроскопії мазків-відбитків м'ясо відповідало ознакам сумнівної свіжості - виявлено грам-позитивні коки до 20 клітин, грамнегативні палички 20-25 клітин у полі зору. Бактерії групи кишкових паличок - це санітарнопоказові мікроорганізми. Їх найбільший рівень забруднення відмічається у випадку неналежного дотримання умов гігієни та санітарії під час виробництва.

Ковбасні вироби виробників ТОВ «Візит» та ТОВ «Єремієвський м'ясокомбінат» досліджували на відповідність ДСТУ 4436:2005 [7].

За органолептичними показниками тільки один зразок сосисок виробника ТОВ «Візит» відповідав всім нормативам. Всі дослідні зразки відповідали НД за зовнішнім виглядом, консистенцією та виглядом фаршу на розрізі. Батон вареної ковбаси та батончики сосисок були 3 чистою сухою поверхнею без пошкодження оболонки, напливів фаршу та жирових набряків. Консистенція виробів пружна і сосиски в гарячому стані соковиті. Фарш на розрізі однорідної структури, світло-рожевий, рівномірно перемішаний, без сірих плям. По показнику «смак та запах» відповідає тільки один зразок сосисок виробника ТОВ «Візит». Ковбаса ТОВ «Візит» та сосиски виробника ТОВ «Еремієвський м'ясокомбінат» мали сторонні присмаки, що є невідповідністю вимог ДСТУ 4436:2005 [7]. 


\section{СІЛЬСЬКЕ ГОСПОДАРСТВО. ТВАРИННИЦТВО}

За мікробіологічними показниками загальної кількості бактерій (МАФАМ), бактерій групи кишкових паличок, патогенні мікроорганізми, у т. ч. бактерії роду Salmonella та Staphylococcus aureus проводили дослідження згідно 3 ГОСТ 10444.15-94, ДСТУ ЕN 12824:2004, ГОСТ 995881, ДСТУ ISO 6888-1:2203 та ДСТУ ISO 68882:2003 [5, 7, 9-11].

Під час дослідження сосисок виробників ТОВ «Візит» та ТОВ «Сремієвський м'ясокомбінат» результати досліджень за мікробіологічними показниками відповідали нормативам [7]. У зразку молочної ковбаси виробника ТОВ «Візит» виявлено невідповідність - МАФАМ перевищує норму в 2,5 рази. Показник МАФАМ - це загальна кількість різних видів мікроорганізмів, до якої входять переважно непатогенні та умовнопатогенні види, які зазвичай не викликають захворювань у людини, але можуть бути причиною виникнення запальних процесів, які розвиваються в разі зниження імунітету організму. Показник характеризує санітарно-гігієнічні режими виробництва і умови зберігання продукції. Продукти, що містять велику кількість життєздатних бактеріальних клітин і не змінюють їх органолептичні показники, не можна вважати повноцінними і свідчить також про його можливе псування.

\section{Висновки:}

1. Під час досліджень за органолептичними, фізико-хімічними та мікробіологічними показниками. Основним мікробіологічним ризиком

\section{БІБЛІОГРАФІЯ}

1. ГОСТ 10444.15-94 Продукты пищевые. Методы определения количества мезофильных аэробных и факультативно-анаэробных микроорганизмов. - М., 2010. - 7 с. - (Межгосударственный стандарт).

2. ГОСТ 21237-75 Мясо. Методы бактериологического анализа. - М., 2000. - 28 с. - (Межгосударственный стандарт).

3. ГОСТ 23392-78 Мясо. Методы химического и микроскопического анализа свежести. - М., 2006. - 7 с. - (Межгосударственный стандарт).

4. ГОСТ 7269-79 Мясо. Методы отбора образцов и органолептические методы определения свежести. - М., 2006. - 7 с. - (Межгосударственный стандарт).

5. ГОСТ 9958-81 Изделия колбасные и продукты из мяса. Методы бактериологического анализа. - М., 2009. - 15 с. - (Межгосударственный стандарт). м'яса та ковбасних виробів є невідповідність показника загального мікробіологічного забруднення (МАФАМ, КУО в 1,0 г) і перевищення показника кількості бактерій групи кишкових паличок, що свідчать про неналежний санітарний контроль під час їх виробництва, зберігання й транспортування.

2. Основна причина невідповідності стандартам якості м'ясних продуктів - високе бактеріальне забруднення, що вказує на порушення санітарно-гігієнічних вимог під час забою, технологічних режимів під час їх виробництва, зберігання, транспортування та реалізації.

Перспективи подальших досліджень. Попередити можливі негативні наслідки під час виробництва м'ясної продукції можна лише за умови здійснення комплексних досліджень на етапах виробництва, зберігання, транспортування та реалізації. Під час виробництва слід застосовувати систему НАССР, засновану на аналізі ризиків та контролю в критичних точках етапів виробництва.

Встановлення в організації постійного контролю виробництва м'ясних продуктів 3 урахуванням оцінки ризиків відповідає сучасним міжнародним принципам і сприяє гарантії безпечності продукції тваринного походження. Така робота $є$ гарантією отримання м'ясної продукції, яка відповідатиме стандартам якості і дасть можливість попереджати порушення технологічних режимів виробництва.

6. ГСТУ 46.019-2002 «Блоки із м'яса та субпродуктів заморожені. ЗТУ». - 2002. - (Мінагрополітики України).

7. ДСТУ 4436:2005 «Ковбаси варені, сосиски, сардельки, хліби м'ясні». - К., 2006. - 31 с. (Держспоживстандарт України).

8. ДСТУ 6030:2008 «М'ясо яловичини та телятини в тушах, півтушах і четвертинах. Технічні умови». - К., 2011. - 18 с. - (Національний стандарт України).

9. ДСТУ ЕN 12824:2004 Мікробіологія харчових продуктів і кормів для тварин. Горизонтальний метод виявлення Salmonella (EN 12824:1997, IDT). - 2005. - 24 с. - (Національний стандарт України).

10. ДСТУ ISO 6888-1:2203 Микробиология пищевых продуктов и кормов для животных. Горизонтальный метод подсчета коагулазаположительных стафилококков (Staphylococcus aureus и другие виды). Часть 1. Метод с приме- 


\section{СІЛЬСЬКЕ ГОСПОДАРСТВО. ТВАРИННИЦТВО}

нением агаровой среды Бейда-Паркера (ISO 6888-1:1999, IDT).

11. ДСТУ ISO 6888-2:2003 Мікробіологія харчових продуктів та кормів для тварин. Горизонтальний метод підраховування коагулазопозитивних стафілококів (Staphylococcus aureus та інших видів). Частина 2. Метод 3 використовуванням фібриногену плазми крові кролика для агарового середовища (ISO 6888-2:1999, IDT). 2004. - 11 с. - (Українське Агентство зі Стандартизації).

12. Клив де В. Блэкберн Микробиологическая порча пищевых продуктов. - СПб. : Профессия, 2008. - $784 \mathrm{c}$.

13. Коиюмбас I. Я. Експертиза напівфабрикатів м'ясних та м'ясо-рослинних січених мікроструктурним методом / І. Я. Коцюмбас, Г. І. Коцюмбас, О. М. Щебентовська // Методичні рекомендації. - Львів : Афіша, 2011. - 80 с.

14. МБТ 5061-89 «Медико-биологические требования и санитарные нормы качества продовольственного сырья и пищевых продуктов. - 1989 . - (Министерство здравоохранения СССР).

15. Обов'язковий мінімальний перелік досліджень сировини, продукції тваринного та рослинного походження, комбікормової сировини, комбікормів, вітамінних препаратів та ін., які слід проводити в державних лабораторіях ветеринарної медицини, і за результатами яких видається ветеринарне свідоцтво (ф-2), затвердженим наказом Державного департаменту ветеринарної медицини України від 03.11.98 N 16 (зі змінами від 18 листопада 2003 р. N 87).

16. Про безпечність і якість харчових продуктів. Закон України від 23 груд. 1997 р. [зі змін. та доп., внесеними Законами України від 13 вер. 2001 р. № 2681-III від 24 жовт. 2002 р. № 191IV].

17. Про ветеринарну медицину. Закон України: № 2775-III від 15 листоп. 2001 р. 